Acta Regionalia et Environmentalica 1

Nitra, Slovaca Universitas Agriculturae Nitriae, 2017, pp. 15-23

\title{
INTERACTIONS BETWEEN CLIMATE CHANGE, WORLD ECONOMICS, AND CLIMATE POLICY
}

\author{
Zsolt PARAPATITS
}

Sopron University , Hungary

\begin{abstract}
Climate change is a major current issue which affects natural, economic and social processes equally. Despite the widespread acclaim of the issue we still encounter economic and political solution models that are climate-sceptic and often contradict each other. As a result, national climate policies and social opinions constantly change in an active interaction with each other. Thus, this current study, based on the latest international literature, reviews and analyses the world economic tendencies, related social and political responses along which different official (national) standpoints are formed. Therefore, the interpretations of related scientific research results are often different, which can easily lead to unsuccessful problem solution.
\end{abstract}

Keywords: global warming, economic adaptability, international climate politics, economic policy interactions, social responses

A continuously growing number of scientific publications have been available on the economic impact of climate change from perspectives that are often different from each other. Most of the literature focuses on climate and environmental impacts that have occurred since the 1970s and only a much smaller number of publications deal with the less obvious social impacts and contexts. Despite all this, I find it important to examine the obvious environmental change from the different economic status of communities, as my assumption is that, in a given economic situation, the emphasis and assessment of climate change related events and their effects on the community involved are different from optimal. As all the 197 countries on our planet increasingly have to face these phenomena, I believe it is worth taking a glance at the differing world economic and international climate policy interactions and processes.

\section{Aims}

This publication - that could possibly serve as a pilot study to larger-scale research, aims to introduce the current and prospective future interactions between world economics and global warming to the reader, and the relating international climate policy changes, based on the analysis of scientific literature. The literature commonly uses a subtheme: natural environmental, political, national economic or social approaches, to present the impacts of climate change. The presentation of the interactions between the subthemes is often neglected, thus, in my study, I attempt to review this "missing link," focusing on research possibilities in the field of political economics, based mainly on the latest international and some Hungarian scientific articles to ensure a larger, broader view. My aim is also to examine the idea that the interpretation of changes in the natural environment is often distorted by mainstream economic and political interests, as well as the reactions of different countries and social groups as a result, which can lead to the unsuccessful handling of the original problem.

It is also important to note that the related scientific literature is in continuous change in terms of content, as we can see the continuous expansion in the starting data of new publications. Thus, a scientific publication (including this present study) can only be viewed as a current snapshot rather than a long-term, unchangeably valid truth.

\section{The age of changes}

Throughout the history of humanity, our predecessors have been witnesses to various series of events that fundamentally influenced, and sometimes changed the economy and the function of society. In relation to climate change concerning the Anthropocene (Crutzen and Stoermer, 2010), unlike the dynamics of the previous historical eras, we have to tackle more global problems: we are continuously rolling the world economic, regional and local imbalances resulting from the uneven pace of development of the global capitalist economy ahead of us, as well as social disorders deriving from the continent-specific differing speed of globalization. We continuously face the growth of the Earth's population, the aging of the national population pyramids in western societies, and the ever growing rate of working age population on a global level as a result of the more optimal use of health expenditure (Eurostat, 2016), and the progressive change of communication and IT technology as a result of fast technical development. All this puts a strain on economic operators and the often poor adaptability of the population. We cannot ignore the differing reactions of communities most affected by the impacts of climate change due to the relativization of social value systems and ideas. A number of up-to-date national and international

Contact address: Zsolt Parapatits PhD-Student, Sopron University, Faculty of Economics, István Széchenyi Management and Organisation Sciences Doctoral School, Hungary, phone +36-30-999-8242, e-mail: parapatits.zsolt@gmail.com 
scientific literature also deals with relationships and mutual effects of the simultaneous challenges that I have outlined (Kulcsár, 2014; Maklári, 2008; Pék, 2013; Jamison, 2010; Gasper, 2011).

\section{Do we have anything to do at all?}

Before introducing different perspectives, it is useful to ask a fundamental question: does global warming, the impacts of which we wish to examine, exist at all? This is where we first encounter the climate-sceptic point of view (e.g. Turnpenny, 2012; Whitmarsh, 2011), which, while in scientific circles is becoming less and less popular, the proportion of believer sceptics is still $17 \%$ in Australia, $15 \%$ in Norway, $13 \%$ in New-Zealand, and $12 \%$ in the USA (Tranter and Booth, 2015). Its argumentation system can probably be best demonstrated by the following quote: "First, they deny that climate change is occurring. Then they say that if it is occurring it's not due to humans. Then they claim that if it is due to humans, the effects are trivial. If the effects are shown to be non-trivial, they opine that the benefits will exceed the damage. If the damage is shown to predominate, they say the cost of avoiding the damage is too high" (Rensburg, 2015). According to scientific logic, it is fundamentally necessary to doubt either an individual theory or views based on certain published, quantifiable results.

Accordingly, we could be scientifically sceptical about climate change either totally or just about certain individual subthemes (Phillips, 2012):

- Evidence scepticism (Trend, Cause, Impact).

- Process scepticism (Scientific and Decision-making).

- Response scepticism (Mode of regulation and its institutions).

Do we settle with this simple, logically structured, but scientifically less and less supportable explanation then? If we do, then what shall we do with the temperature data, based on hundreds of independent, precise data collections every year, as a result of which a continuous, accelerating rise in average global temperature can be seen both on the northern and the southern hemisphere? (Datagrawer, 2015)

\section{If we don't deny the change, then do we influence it?}

If we take the quantifiable facts regarding climate change into account, then the simplest and fastest way to publish this information reaching the widest audience is through mass media, which, however, is greatly influenced by different economic, political and social interest groups. (Carvalho, 2010.) We can inspect its graphic appearance dynamics continent by continent relating to the results of the chart below (Boykoff and Yulsman, 2013; Anderson 2011).

From the research conducted in 20 countries on 6 continents, it can be determined that between 2004 and 2013, the newspapers in Oceania (the area most exposed to the natural and economic impacts of climate change) and North-America dealt with the issue to an outstanding degree, while in Asia, Africa and South-America, the publication rate was less than half of the above. The extremely wide publicity can be attributed to Vice-president Al Gore's environmental campaign in 2006 and 2007, the events of the unsuccessful Copenhagen Climate Conference in 2009, while the appearance rate of the past few years were at $20-25 \%$ of these peaks, partly due to the changes in economic and social priorities after the international financial crisis of 2008-2009 (Kirilenko and Stepchenkova, 2012).

The PEW (2016) (PEW Research Center: Nonpartisan American public opinion polling association, based in Washington DC. USA) study shows the influencing role of mass media in an interesting way, where $72 \%$ of Republican US voters think that the significance of climate change is overrated by the mass media, while $64 \%$ of liberal Democrats believe that the mass media deal with this essential issue too little. The information broadcast by the media is only accepted as fair and realistic by a mere 8 to $26 \%$ of the adult population regardless of party preference. Besides these results of course, we do not debate the strong indirect and direct influencing role of mass media on individuals and social groups (Eskjaer, 2013).

\section{WGDP and Climate Change}

Provided we accept the existence of global climate change, we can see research results confirming our viewpoint (Kulcsár, 2013; Tapia, 2012) if we examine the impact of climate change on the performance of global economy, especially in relation to change in $\mathrm{CO}_{2}$ concentration that is proclaimed to be the main cause of global warming. It is clear from the research (Tapia, 2012; HVG, 2012) that despite expectations there is no essential connection between the rise in global population and $\mathrm{CO}_{2}$ levels, however, a close relationship has been revealed between global GDP and annual change in $\mathrm{CO}_{2}$ concentration, which confirms our original hypothesis about the primary relevance of an economic perspective.

The above finding is confirmed in the long term by the analysis in the article of New Scientist (2012) as well, according to which global GDP loss caused by climate change was only $0.5 \%$ higher in 2012 than the cost of halting

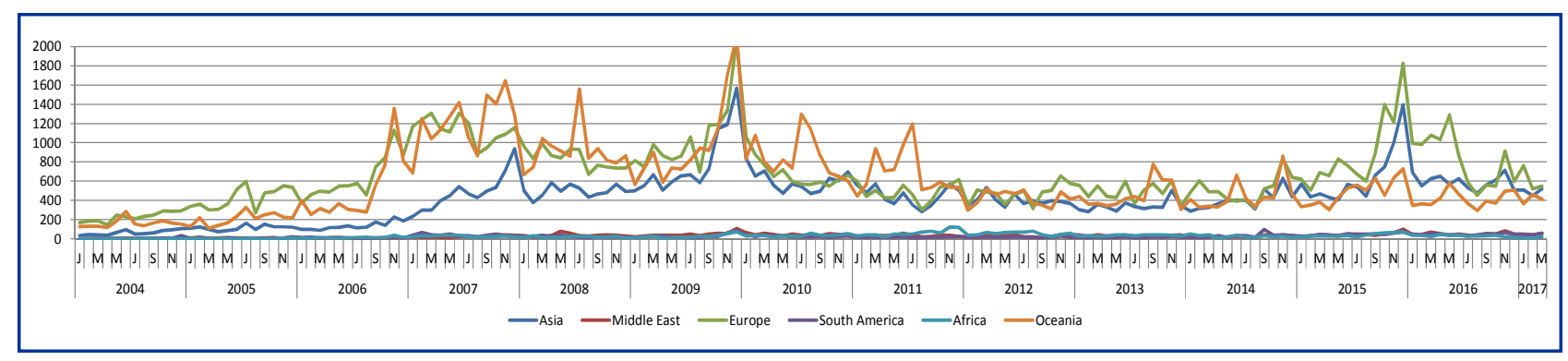

Figure 1 Media reports on climate change 2004-2017

Source: Boykoff, M. et al. 2017 


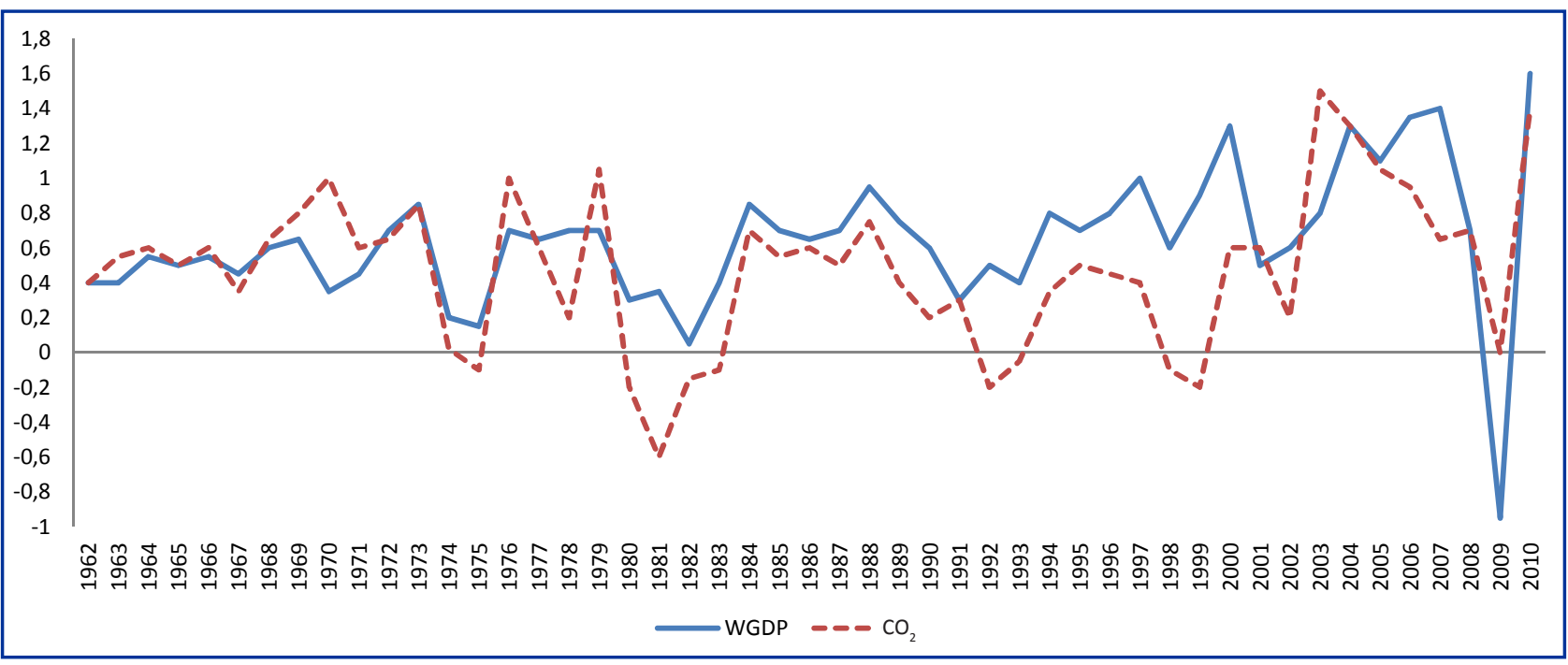

Figure 2 Annual growth of world GDP (blue line, trillions of 2000 US dollars), and annual change of estimated $\mathrm{CO}_{2}$ emissions (millions of Kt, red rugged line)

Source: adapted from Tapia G. et al. (2017)

the process, while this loss will have risen to an annual 3.2\% by 2030 . In the near future, this will cause serious problems, especially with WGDP's annual growth being 2-3\% after 2011 (data.worldbank.org).

\section{Periodic responses to climate change}

I present the past and future periodic modifications in global economy guidelines regarding climate change from 1990 up to now in 3 (Levy and Spicer, 2013; Jones and Levy, 2007), +1 (Székely, 2011) phases, assuming certain determinable main directions in economic reactions to the given temporal effects of climate change:

1. Fight for coal-based energy: the 1990s, when the growing concern about climate change was not yet strong enough to change the coal-based economic model; owing to the successful consumption-boosting and exclusively growth-oriented economic policies of multinational companies with a high need and consumption of energy.

2. Carbon-compromise: The period between 1998 and 2008, when the effects of climate changes inevitably resulted in the restriction of fossil energy consumption, while the search for business possibilities with a low energy demand accelerated. The result of this period is the intensification of Eco-fanaticism (Maklári, 2008) and the evolving Techno-market model which will be discussed later on.

3. Climate dead end: The consequence of the 2009 global financial crisis, when the energy companies, partly as a result of the crisis, moved again towards fossil energy sources, but this was not considered as the final business solution. Along with a slight rise in green energy consumption, energy-intensive sectors slowly switched to alternative energy sources and the social concerns regarding climate change were temporarily marginalized. The focus was on the recovery from the financial-economic crisis.

4. The chance of the future: Cortex age (Székely, 2011): since 2015, the Paris Climate Change Conference has partly ratified the vigorous conversion to renewable energy sources in the economy, initiated by developed countries, which, from an optimistic-utopistic viewpoint, could even mean the beginning of an environmentally conscious social model change first in global consciousness and, as a result, in market economy.

\section{International and/or Folk Games}

Due to the differing levels of national adaptability, economic viewpoints and vulnerability, the lack of compromise is well represented by the Copenhagen Climate Conference (2009), which is often just referred to as a negative example. The implications of this international conference are widely dealt with by the literature (Perlmutter and Rothstein, 2011; Carraro and Massetti, 2012; Trevors and Saier, 2010), while the standpoints of participating countries diverging from the ideal median that would have led to a solution were assessed by several studies (Bailer and Weiler, 2014; Trevors, 2010; Cartera, 2011).

The fundamentally common conclusion of the studies is that despite popular belief, the participating countries did not only take bargaining positions based on their economic and social structure, but they surprisingly formed groups according to their common strategic interests. It was obvious from the research that the countries more economically and geographically vulnerable to climate change were mostly willing to compromise on funding of $\mathrm{CO}_{2}$ emission reduction and their standpoints showed much smaller differences from each other, they were only "centimetres" from an agreement.

However, the increase of a country's GDP detectably interfered with its willingness to compromise and encouraged it to wait out, even when democratic countries were statistically more prone to compromise than their totalitarian counterparts.

A higher quality of natural surroundings in a country itself proved as a strong incentive for a mutual agreement as well, but they were not sufficient in terms of their numbers to create a joint concluding document, including positive commitments. It is important to note that democratic 
countries were not necessarily more accepting in terms of giving up community welfare and changing their economic goals than their developing or anti-democratic counterparts. In favour of realising the emission goals, they rather agreed to provide financial support that was not easy to keep in the future in order to offset their lack of direct willingness to compromise, and they rather voluntarily committed to obligations and a cooperative role in less cardinal and low budget negotiation subfields (Cartera, Cleggs and Wåhline, 2011).

As opposed to this, the Paris Climate Agreement signed on 12 December 2015 can seem reassuringly positively based on the media coverage (Faragó, 2015). Although its fundamental merit and difference from the Copenhagen Conference is that the agreement to stop and reverse the $+2^{\circ} \mathrm{C}$ average global temperature change by 2100 is universally accepted, it is still only theoretical. The exact contributions of the participating countries will only be individually specified in the following years and developing countries will only take practical measures towards reducing $\mathrm{CO}_{2}$ emission if they receive financial support from developed countries (UNFCCC, 2015). The final document refers only indirectly to the optimal rate and scheduling of $\mathrm{CO}_{2}$ reduction. The differing economic perspectives of countries can prevail here as well, since the framework agreement does not contain specific sanctions, which could greatly influence national economic policies. Along with successful realization of the Paris agreement - according to the report by the UN's Environmental Programme (UNEP, 2016) - the present contributions will still not be sufficient, and the prospective average rise in temperature will reach $+2.9-3.4^{\circ} \mathrm{C}$ degrees by the end of the $21^{\text {st }}$ century, so at present, there is no common economic ground (viewpoint) that would enable the reversal of the process (Piac\&Profit, 2016).

\section{Temporal impact of climate agreements on global warming}

The history of the climate agreement mentioned above starts far back in 1992 (Faragó, 2015). The United Nations Framework Convention on Climate Change (UNFCCC) was accepted that year, aiming to internationally prevent climate change that was expected to have dangerous consequences. Since then, there has been no successful

Table 1 Minimum damage estimates for alternative emissions paths, for selected probabilities of exceeding the relevant warming level. The risk-weighted outcome is calculated by multiplying the probability of warming in 2100 with eachimpact response function. Likelihood values based on IPCC (2007)

\begin{tabular}{|c|c|c|c|c|c|c|}
\hline & \multicolumn{6}{|c|}{ Likelihood of crossing treshold/proportion of loss/extent of reduction in overturning (\%) } \\
\hline & $\begin{array}{c}\text { highly likely } \\
(90 \%)\end{array}$ & likely (67\%) & $\begin{array}{c}\text { even chance } \\
(50 \%)\end{array}$ & $\begin{array}{l}\text { unlikely } \\
(33 \%)\end{array}$ & $\begin{array}{l}\text { highly unlikely } \\
(10 \%)\end{array}$ & risk weighted \\
\hline \multicolumn{7}{|c|}{ MEP at 2030 (Ref) } \\
\hline Warming $\left(\mathbf{C}^{\circ}\right)$ & 2,8 & 3,3 & 3,7 & 4 & 4,7 & \\
\hline Greenland ice sheet & 78 & 86 & 88 & 90 & 96 & 87 \\
\hline Coral reef damage & 92 & 96 & 98 & 99 & 100 & 97 \\
\hline Species extinction risk & 28 & 42 & 55 & 64 & 82 & 71 \\
\hline Reduced THC overturning & 25 & 30 & 34 & 37 & 44 & 34 \\
\hline \multicolumn{7}{|c|}{ MEP at 2020} \\
\hline Warming $\left(\mathrm{C}^{\circ}\right)$ & 1,9 & 2,3 & 2,5 & 2,8 & 3,3 & \\
\hline Greenland ice sheet & 47 & 64 & 71 & 78 & 86 & 70 \\
\hline Coral reef damage & 84 & 88 & 90 & 92 & 96 & 90 \\
\hline $\begin{array}{l}\text { Extent of species } \\
\text { extinction }\end{array}$ & 11 & 17 & 21 & 28 & 42 & 27 \\
\hline $\begin{array}{l}\text { Reduction in THC } \\
\text { overturning }\end{array}$ & 16 & 20 & 22 & 25 & 30 & 23 \\
\hline \multicolumn{7}{|c|}{ MEP at 2010} \\
\hline Warming $\left(\mathrm{C}^{\circ}\right)$ & 1,1 & 1,4 & 1,6 & 1,8 & 2,2 & \\
\hline Greenland ice sheet & 9 & 22 & 32 & 42 & 60 & 34 \\
\hline Coral reef damage & 68 & 75 & 79 & 82 & 87 & 79 \\
\hline $\begin{array}{l}\text { Extent of species } \\
\text { extinction }\end{array}$ & 4 & 6 & 8 & 10 & 15 & 9 \\
\hline $\begin{array}{l}\text { Reduction in THC } \\
\text { overturning }\end{array}$ & 8 & 11 & 13 & 15 & 19 & 14 \\
\hline
\end{tabular}

Source: adapted from Shennan et al. (2008)

All figures in percent unless otherwise indicated 
transnational cooperation concerning the reduction of global warming, except for the 1997 Kyoto Protocol.

The disadvantages of this will probably be increasingly perceived in the near future. According to the comparison tables in the research by Shennan, Jones and Jolley (2008), if we adhere to the Minimal Emission Path (MEP 2030), only an international agreement back in 2010 would have been able to achieve the current $\mathrm{CO}_{2}$ emission and average temperature targets.

In this case, the annual $\mathrm{CO}_{2}$ emission levels will have been stabilized by the 2030s, and the previous negative consequences will have disappeared at a slowing rate by the end of the $21^{\text {st }}$ century. The alternative climate scenarios seen on Table 1, show the expected environmental changes which lead to further negative global consequences owing to the delayed agreements that are due to the lack of consensus caused by the differing economic viewpoints. However, besides the collective indecisiveness, the participating (mainly developed) countries have taken positive steps as well, along with their individual economic interests in the past few years in an environment of rapid technological development. The practical results of this can be seen in the latest report of the International

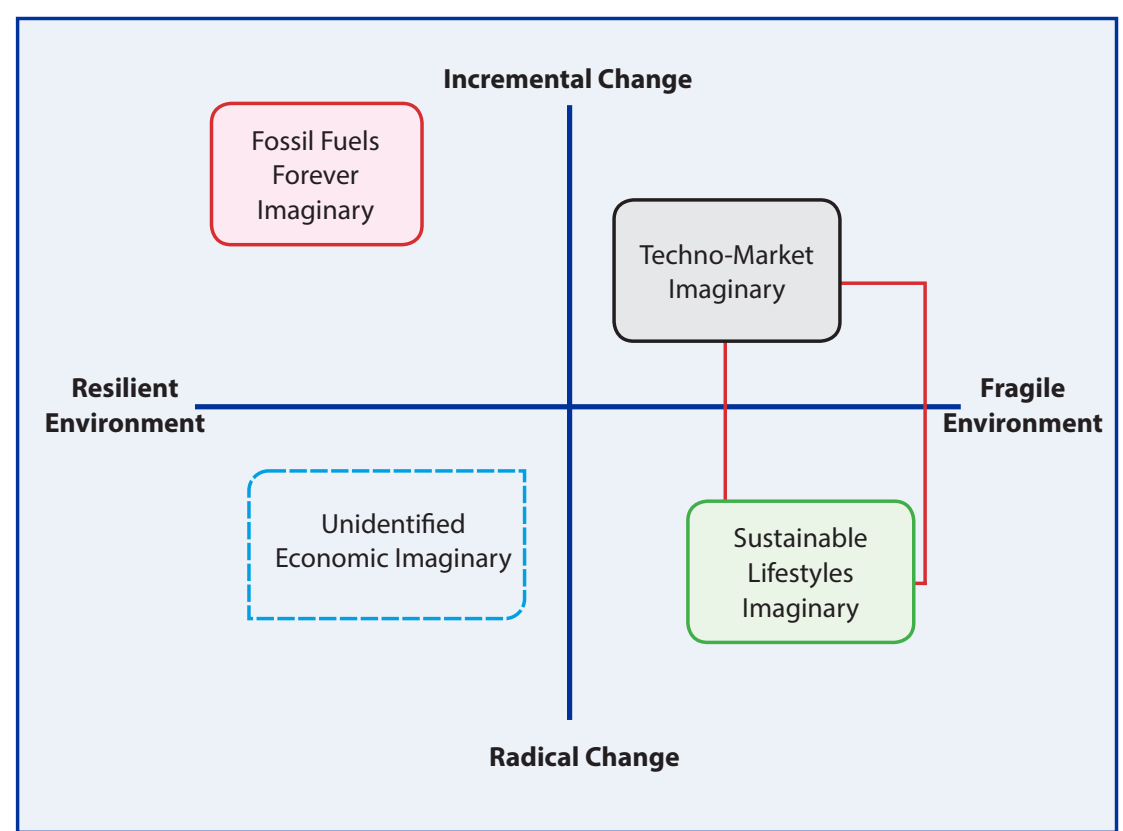

Figure 3

Climate Change Imaginaries

Source: adapted from Levy and Spicer (2013)
Energy Agency (IEA 2015), according to which 500'000 solar panel units were installed daily on a global level in 2015; and only in China - where $40 \%$ of the annual renewable energy capacity growth is manifested - on average 2 wind turbines per hour were installed.

In this respect, the predictions suggest further positive changes as in the next 5 years; further permanent growth is expected with the installation of on average $30^{\prime} 000$ solar panel units and 2.5 wind turbines globally every hour by 2021. If the outlined dynamics can be maintained, then, a $28 \%$ share of renewable energy sources can be achieved instead of the current $21 \%$, even with a lack of international cooperation, concerning the full energy production. This growth will presumably be the result of the greater participation of developing countries (REN21, 2016).

\section{The fight of dominant ideas for a successful solution}

As far as popular economic ideas are concerned, we like to assume that these concepts, evolving continuously, determine the actions and economic achievements of different social groups for longer periods of time. However, as opposed to this, we experience that at the beginning of the $21^{\text {st }}$ century, this linearity is no longer obvious, the competing economic perspectives and world views may take effect simultaneously, and they can intensify each other's impacts, or on the contrary, cripple them. They can make countries with a similar geographical environment and roughly identical cultural foundations successful to a different extent.

In their study, Levy and Spicer (2013) summarize the current dominant ideas regarding climate change on an axis of continuously growing change or a sudden radical change, and in the context of a fragile or adaptive natural environment. According to this study, four different economic viewpoints are fighting for permanent survival in western societies on the one hand, and for a dominant society-leading role on the other hand.

All four perspectives go back more than 100 years, but their simultaneous existence and impact was made possible by the liberal social value system and the rapid acceleration of interpersonal communication. Three out of the four examined individually existing and scientifically sound perspectives assume a particularly fragile and continuously changing natural environment. However, we have no working and accepted economic/ social model for a natural environment that is radically transforming but has the ability to adapt flexibly.

The ideal place for the Fossil fuels forever model is the self-renewing natural environment that is changing continuously and at a predictable speed and is able to process the environmental pollution that goes with the present economic activity in the long term, and only slightly requires the change of the existing economic system. This model has been continuously operated by the members of the global economy for nearly a hundred years. Shale gas and petroleum extracted in the past decade as a result of the technological advancement have created a vast amount of reserves, which helps the long-standing economic model and provides additional time to tackle climate-adaptation problems (Michaelides, 2016; Wilson and Suebsiri, 2011).

The Climate Apocalypse model is the exact opposite of the above. With 
its excessively negative vision of future and a tendency for populism making it attractive for the mass media, it often does not do more than raise general awareness. Apart from the support of a few NGOs (Non Governmental Organization) its unscientific radicalism and counterproductive effect does more harm than good to acquire knowledge about factual, correct viewpoints. Policy makers do not prefer to support this point of view partly because the preparation for the outlined excessive changes is impossible in such a short time, or partly because fending off the suggested negative environmental and social impacts along with the resulting recession caused by the reduction of consumption would require such tremendous resources that it would be unreasonable for most countries (Wynne, 2010). Even the Sustainable lifestyle model would be a more favourable global solution.

The Sustainable lifestyle model is an idea propagating a greatly alternative economic perspective. It has been added to the possible mainstream solution strategies concerning climate change following the 2009 financial crisis. Its growing popularity has been achieved by a sustainable consumption model, which basically builds on local supply

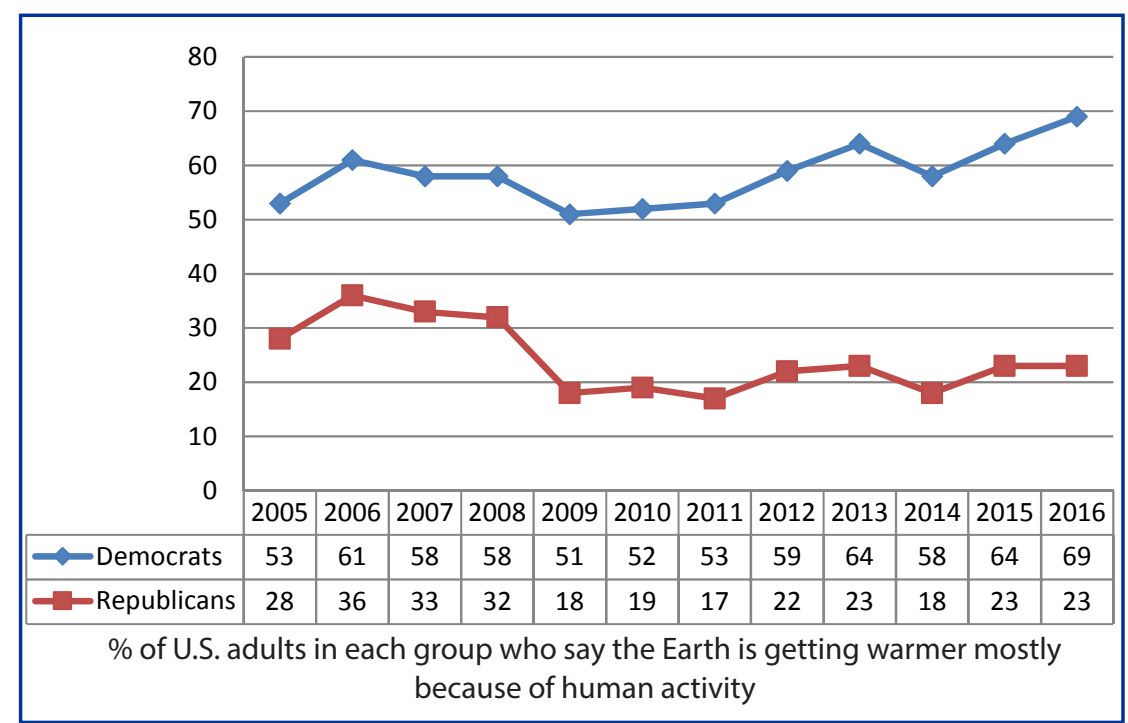

Figure 4 A decade of political divides over Climate Change

Source: adapted from PEW Research Center (2016)

Note: Republicans and Democrats include independents and other non-partisans who "lean" toward the parties. Respondents who do not lean toward a political party, those saying "don't know," and other responses are not shown and local communities. In contrast with the Techno-market model that requires fast-paced transformation, it expects a slower but more radical change concerning individual lifestyle from its followers, which an average western citizen is still not prepared for (Black and Cherrier, 2010; Annala et al., 2016). It initiates changes in the social value system that builds on the currently dominant economic model, and it desires to replace the consumer-style approach with attempts at alternative economic models. Using the resources of the civil society, it would strengthen the decision-making role of local communities, promote countryside lifestyle and it would rely less on the omnipresent technological solutions. The curiosity of this perspective is that its impact is of strongly cultural nature, although the maintenance of the lifestyle "required" from its followers is still relatively costly, e.g. fair-trade and organic products are considerably more expensive than their ordinary counterparts, thus, it is not only the national public opinion (WWF, 2016a) that regards this strongly progressive perspective as elitist.

In the past years, a number of international studies (e.g. pl. Bullard and Müller, 2012; Adua, York and SchuelkeLeech, 2015) have been conducted on

(1) , promising at least linear economic growth, is favourable on several levels, as it minimises the necessity for political change, leaving the current neo-liberal foundations of economic growth intact, and due to its popular acclaim, it makes this adaptive capitalist globalization scheme suitable for follow-on. All this, besides the fact that carbon trade, regarding the stock market trade of $\mathrm{CO}_{2}$ allowances, has received numerous accusations, deeming the current process corrupt and inefficient (Lohmann, 2006).

\section{Politically different climate versions}

Regarding my chosen topic, we cannot disregard the inspection of political ideas and trends that play a vital role in the creation and sustenance of different economic viewpoints, as the political and economic groups affecting the entire society can influence - with the 


\begin{tabular}{|c|c|c|c|}
\hline Cons Rep & Mod/lib Rep & Mod/cons Dem & Liberal Dem \\
\hline General Public 56\% & Climate scientists 69\% & Climate scientists 76\% & Climate scientists 80\% \\
\hline $\begin{array}{c}\text { Climate scientists 48\% } \\
\text { Energy industry } \\
\text { leaders 60\% }\end{array}$ & $\begin{array}{c}\text { Energy industry } \\
\text { leaders 60\% }\end{array}$ & $\begin{array}{c}\text { Leaders from other } \\
\text { nations 59\% }\end{array}$ \\
\hline $\begin{array}{c}\text { Leaders from other } \\
\text { nations 29\% }\end{array}$ & $\begin{array}{c}\text { Leaders from other } \\
\text { nations 43\% }\end{array}$ & $\begin{array}{c}\text { Leaders from other } \\
\text { nations 50\% }\end{array}$ & Elected officials 55\% \\
\hline $\begin{array}{c}\text { Elected officials 29\% } \\
\text { General Public 52\% }\end{array}$ & Elected officials 41\% & Elected officials 55\% & Energy industry \\
leaders 51\%
\end{tabular}

$\%$ of U.S. adults who say each group should have a major role in making decisions about policy issues related to global climate change

Figure 5 Review distribution of political viewpoints

Source: adapted from PEW Research Center (2016)

Note: Republicans and Democrats include independents and other nonpartisans who "lean" toward the parties. Respondents who do not lean toward a political party, those saying "don't know," and other responses are not shown

help of the communication channels enjoying their support - not only the views of their own supporters but also the entire public's opinion on, in this case, international climate policy.

The presented surveys (PEW, 2016 \& WWF, 2016a) are up-to-date in various respects at the time of conducting this study. The results of the 2016 USA presidential election, for example, affect the general assessment of climate change as a scientific and world economic problem and the planned political and economic measures on a global level. Regarding the different economic perspectives, it is worth mentioning that while $61-69 \%$ of people among the adult population of the USA supporting the liberal value system considered global warming mainly the result of human activity in the past decade (PEW, 2016), only $23 \%$ (down from $36 \%$ in 2006) of Republican voters think alike.

If we examine the results regarding the scope of authority in decisionmaking concerning climate change, the US conservative Republican voters would give a leading role to the public opinion (56\%) in decision-making and rulemaking processes. The supporters of other political wings, even liberal democrats, would give a continuously increasing role to climate researchers $(69-80 \%)$ in the first place, while at the other parties, energy companies are in the stable second place as a result of their significant capital power, at levels of around $60 \%$ (PEW, 2016).

A real consensus emerges only in the case of elected representatives as, almost regardless of party preference, the surveyed people slightest give words to them in climate policies and the related decision-making processes (29-51\%).

WWF Hungary conducted a new representative study regarding the latest public views on climate change in September 2016 (WWF, 2016a). The dynamics of this change is rather similar to US research results, as in the past years, the interest of the Hungarian public in the impacts of global climate change shows a significant decline in its order of importance, falling to fifth place in 2016 from third place in 2010 (the preference index has dropped from 8.9 to 8.5$)$. In my opinion, the research results cannot be regarded as unique because of their geographical position, as we can assume powerful economic operators behind dominant political parties in other countries regardless of their economic development, and the political successes achieved by these parties typically enhance the practical realizations of the supporting groups' economic views.

Another survey concerning the elected and appointed representatives (Sautter and Twaite, 2009) shows interesting results within the period between 1997 and 2005. It was found out that in the USA states where the representatives were elected directly, $\mathrm{CO}_{2}$ emission regulations were much more lenient on a state level (about 1.5-fold), as representatives tended to comply with the interests of the economic groups supporting them. However, in the states where representatives were appointed, the appointed representatives were consistently able to make forwardlooking, independent decisions devoid of influence by economic interest groups, in favour of satisfying the longterm needs of the population and the natural environment.

\section{Conclusions}

Could global warming be the most flexibly applied scientific concept of the world? Certainly not, as based on the growing number and detailed scientific research conducted in the past decades, seemingly permanent trends and conclusions can be drawn up about the speed and diversity of its economic and climate policy interactions. However, mass media, permanently influenced by interest groups with differing goals and perspectives, daily offer a poor but differentially alarming picture about the process of climate change. The results are often shown distorted and as a distant process in time and space, isolated from local problems. Thus, they play into the hands of corporations, states, political and economic interest groups which, in order to maintain the trust in the operation of world economy, the existing societygoverning and decision-making model, are willing to largely subordinate even the content, commitments, and timetables of international climate agreements to national or selfinterests. Unfortunately, they disregard the signals of countries and vulnerable social groups that directly suffer from the resulting disadvantages.

Based on this, the presented comprehensive analysis suggests that the current problem-solving models cannot be regarded as stable at all, they don't have uniform political support, they are mostly ad hoc and they only pursue long-term goals from a world economic perspective. As a result, the prevailing ideas and agreements about the successful handling of climate change could be inadequate. 


\section{Possible research directions}

Reviewing the literature used in this research and further studies about the Sustainable Lifestyle Model, which is yet underrepresented in the national scientific literature, we can see that it stands out as exciting due to its uniqueness and its divergence from the traditional consumer value system, as we can only effectively reduce our average global consumption of 1.6 Earths (WWF, 2016b) by real changes in our value system. Thus, a logical step in determining the research aims for the near future could be to examine the value system background of the Sustainable Lifestyle Model.

Climate research (in terms of differing local temperature changes), and economic studies (in terms of e.g. the change in the concentration of capital strength) consider cities differently from their immediate surroundings and the countryside. This unique and increasingly powerful central role could serve as a favourable direction for scientific research of the relationships, and mutual effects between Residential communities, modern cities, and Sustainable lifestyle, as the justification of this economic model will be decided on a global level in a fast-growing, urbanized environment.

By the beginning of the $21^{\text {st }}$ century, the accelerated technological development has brought not only daily organizational changes for employees but also the need for the renewal of management. The large scale transformation of industrial production (e.g. Industry 4.0) and the "Investigation of creative management theory models in the fight against climate change" privileging the retainment and improvement of market positions would mean a new and interesting research perspective to explore the synergies of these two parallel substantial change processes.

\section{References}

ADUA, L. - YORK, R. - SCHUELKE-LEECH, B.A. 2015. The human dimensions of climate change: A micro-level assessment of views from the ecological modernization, political economy and human ecology perspectives. In Social Science Research, 2015, pp. 1-18.

ANDERSON, A. 2011. Sources, media, and modes of climate change communication: the role of celebrities. In WIREs Clim Change, 2011 no, 2, pp. 535-546.

ANNALA, S. - VILJAINEN, S. - PAKKANEN, M. - HUKKI, K. 2016. Consumer preferences in engaging in a sustainable lifestyle. Int J. Innovation and Sustainable Development, vol. 10, 2016, no. 1. pp. $1-18$.

BAILER, S. - WEILER, F. 2014. A political economy of positions in climate change negotiations: Economic, structural, domestic, and strategic explanations. Springer Science \& Business Media, New York, 2014.

BLACK, I. R. - CHERRIER, H. 2010. Anti-consumption as part of living a sustainable lifestyle: Daily practices, contextual motivations, and subjective values. In Journal of Consumer Behaviour, 2010, no. 9, pp. 437-453.

BOYKOFF, M. T. - YULSMAN, T. 2013. Political economy, media, and climate change: sinews of modern life. In WIRE's Climate Change, 2013, no. 4, pp. 359-371. doi:10.1002/wcc.233.

BOYKOFF, M. et al. 2017. Worl Newspaper Coverage of Climate Change or Global Warming, 2004-2017. Center for Science and Technology Policy Research, Cooperative Institute for Research in
Environmental Sciences, University of Colorado. Web. [Acces: 2017 July 20], http://sciencepolicy.colorado.edu/media_coverage

BRYANT, G. 2016. The Politics of Carbon Market Design: Rethinking the Technopolitics and Post-politics of Climate Change. In Antipode, vol. 48, 2016, no. 4, pp. 877-898.

BULLARD, N. - MÜLLER, T. 2012. Beyond the 'Green Economy': System change, not climate change? In Development, 2012, no. 55, pp. 54-62.

CARRARO, C. - MASSETTI, E. 2012. Beyond Copenhagen: a realistic climate policy in a fragmented world. In Climatic Change, 2012, no. 110, pp. 523-542.

CARTERA, C. - CLEGGC, S. - WÅHLINE, N. 2011. When science meets strategic realpolitik: The case of the Copenhagen UN climate change summit. In Critical Perspectives on Accounting, 2011, no. 22, pp. 682- 697.

CARVALHO, A. 2010. Media(ted) discourses and climate change: a focus on political subjectivity and (dis)engagement. In WIREs Clim Change, 2010, no. 1, pp. 172-179.

CRUTZEN, P. J. - STOERMER, E. F. 2000. The 'Anthropocene.' In Global Change Newsletter, 2000, no. 41, pp. 17-18.

DATAGRAWER. 2016. World temperature anomalies for februari 2016. Retrieved: 05 Nov 2016. from: http://www.datagraver.com/ case/world-temperature-anomalies-for-februari-2016

ESKJÆER, M. 2013. The Regional Dimension: How Regional Media Systems Condition Global Climate-Change Communication. In Journal of International and Intercultural Communication, vol. 6, 2013, no. 1, pp. 61-81.

EUROSTAT. 2016. Regionális szintű népesség statisztika Retrieved: 03. Jan 2017. from: http://ec.europa.eu/eurostat/statisticsexplained/index.php/Population_statistics_at_regional_level/hu FARAGÓ, T. 2015. Új nemzetközi éghajlatvédelmi megállapodás. In Magyar Energetika, 2015, no. 5-6, pp. 58-61.

GASPER, R. - BLOHM, A. - RUTH, M. 2011. Social and economic impacts of climate change on the urban environment. In Environmental Sustainability, 2011, no. 3, pp. 150-157.

http://data.worldbank.org/indicator/NY.GDP.MKTP.KD.ZG

HVG. 2012. Meglepő összefüggésre bukkantak a GDP és a klímaváltozás között. Retrieved: 28. januar 2012. from: http://hvg.hu/gazdasag/20121008_Meglepo_osszefuggesre_ bukkantak_a_GDP_es_

INTERNATIONAL Energy Agency. 2015. WEO - 2015 Special Report on Energy and Climate Change. Retrieved: 21 october 2016. from: http://www.iea.org/publications/freepublications/publication/ weo-2015-special-report-2015-energy-and-climate-change.html

JAMISON, A. 2010. Climate change knowledge and social movement theory. Wiley Interdisciplinary Reviews. In Climate Change, vol. 1, 2010, pp. 811-823.

JESSOP, B. 2010. Cultural Political Economy and Critical Policy Studies. In Critical Policy Studies, 2010, no. 3, pp. 336-356.

JONES, C. A. - LEVY, D. L. 2007. North American Business Strategies Towards Climate Change. In European Management Journal, vol. 25, 2007, no. 6, pp. 428-40.

KIRILENKO, A. P. - STEPCHENKOVA, S.O. 2012. Climate change discourse in mass media: application of computer-assisted content analysis. In J Environ Stud Sci, 2012, no. 2, pp.178-191.

KULCSÁR, L. 2013. A klímaváltozás társadalmi-gazdasági hatása. Retrieved: 21. january 2017. from: publicatio.nyme. hu/254/1/01KulcsarLaszlo.pdf

KULCSÁR, L. 2014. Klímaváltozás és társadalmi változás. Gazdaság \& Társadalom. In Journal of Economy \& Society, 2014, no. 1, pp. 3-14. LEVY D. L. - SPICER, A. 2013. Contested imaginaries and the cultural political economy of climate change. In Organization, vol. 20, 2013, no. 5, pp. 659-678. 
LOHMANN, L. 2006. Carbon Trading: A Critical Conversation on Climate Change, Privatisation and Power. London : Routledge, 2006. MAKLÁRI, T. 2008. Klímahisztéria és egyéb gyógyítható betegségek. Budapest : Studium Bt., 2008.

MICHAELIDES, E. E. 2016. A New Model for the Lifetime of Fossil Fuel Resources. In Natural Resources Research, 9. August 2016. NEW Scientist. 2012. Climate harms today's economy. Retrieved: 2012. september 29. from: https://www.newscientist.com/

PÉK, T. 2013. A Mitől vagy Kitől változó klíma. Szülőföld Könyvkiadó, Szombathely.

PERLMUTTER, D. D. - ROTHSTEIN, R. L. 2011. The Challenge of Climate Change: Which Way Now? Prospects After Copenhagen, ch. 11. John Wiley \& Sons, Ltd., 2011, pp. 188-218.

PEW Research Center. 2016. The Politics of Climate. Retrieved: 04 october 2016. from: http://www.pewinternet.org/2016/10/04/ the-politics-of-climate/

PHILLIPS, A.T. 2012. Climate Change: Scepticism versus Objectivity? In Science as Culture, vol. 21, 2012, no. 4, pp. 607-610.

PIAC \& Profit. 2016. Ha elérjük a klímaegyezmény céljait, még nem vagyunk sehol. Retrieved: 04 november 2016. from: http://www.piacesprofit.hu/klimablog/klimaegyezmenynem-eleg-de-legalabb-van/?utm_source $=15338$-A KLIMABLOGHIRLEVEL\&utm_campaign $=273716-\mathrm{KI} \% \mathrm{C} 4 \% 82 \% \overline{\mathrm{C}}$ 2\%ADmablogh\%C4\%82\%C2\%ADrlev\%C4\%82\%C5\%A0I\&utm _medium $=12055$-email\&utm_content $=1107$

RENSBURG, W. V. 2015. Climate Change Scepticism: A Conceptual Re-Evaluation. In SAGE Open April-June 2015, pp. 1-13.

REN21. 2016. Renewables 2016 Global Status Report. Retrieved: 23.january2017.from:http://www.ren21.net/status-of-renewables/ global-status-report/

SAUTTER, J. A. - TWAITE, K. 2009. A Fractured Climate? The Political Economy of Public Utility Commissions in an Age of Climate Change. In The Electricity Journal, vol. 22, 2009, no. 6, pp. 68-76.

SHEEHAN, P. - JONES, R. N. - JOLLEY, A. 2008. Climate change and the new world economy: Implications for the nature and timing of policy responses. In Global Environtament Change, 2008, no. 18, pp. 380-396.

SZÉKELY, Cs. 2011. Gazdaságfejlesztés a reformkorban és a XXI. században. Gazdaság \& Társadalom. In Journal of Economy \& Society, 2011, special issue, pp. 3-15.
TAPIA, G. - JOSE, A. - IONIDES, E. L. - CARPINTERO, O. 2012. Climate change and the world economy: short-run determinants of atmospheric $\mathrm{CO}_{2}$. In Environmental Science \& Policy, 2012, no. 21, pp. 50-62.

TRANTER, B. - BOOTH, K. 2015. Scepticism in a changing climate: A cross-national study. In Global Environmental Change, 2015, no. 33, pp. 154-164.

TREVORS, J.T. - SAIER, M.H. 2010. UN Climate Change Conference, Copenhagen 2009: Whatever Works? In Water Air Soil Pollution, 2010, no. 207, pp. 1-3.

WYNNE, B. 2010. Strange Weather, Again: Climate Science as Political Art. In Theory, Culture, and Society, vol. 27, 2010, no. 2-3, pp. 289-305.

TURNPENNY, J. R. 2012. Lessons from post-normal science for climate science-sceptic debates. In WIREs Clim Change, 2012, pp. 357-364.

UNEP. 2016. Unep Frontiers 2016 Report, Emerging Issues of Environmental Concern. Retrieved: 21. january 2017. from: https:// web.unep.org/frontiers/sites/unep.org.frontiers /files/documents/ unep_frontiers_2016.pdf

UNFCCC. 2015. Adoption of the Paris Agreement. Retrieved: 21. january 2017. from: https://unfccc.int/resource/docs/2015/ cop21/eng/l09r01.pdf

WHITMARSH, L. 2011. Scepticism and uncertainty about climate change: Dimensions, determinants, and change over time. In Global Environmental Change, 2011, no. 21, pp. 690-700.

WILSON, M. - SUEBSIRI, J. 2011. A model of carbon capture and storage with demonstration of global warming potential and fossil fuel resource use efficiency. In Energy Procedia, 2011, no. 4, pp. 2465-2469.

WWF Magyarország. 2016a. Kit érdekel a természet- és környezetvédelem? Retrieved: 17. november 2016. from: http://wwf.hu/egyeb-termeszetvedelem_/1/kit-erdekel-atermeszet-es-kornyezetvedelem

WWF Magyarország. 2016b. Hamarabb jött el a túlfogyasztás napja. Retrived: 20. november 2016. from: http://wwf.hu/klima_/1/ ismet-hamarabb-jott-el-a-tulfogyasztas-napja 